\title{
AGENDA CULTURAL HERITAGE AND THE FUTURE OF ARCHAEOLOGY AT SWEDEN'S COUNTY MUSEUMS
}

\author{
Alexander Gill \\ Brännkyrkagatan 42, 11822 Stockholm, Sweden \\ alex.gill@bredband.net
}

Archaeology at Sweden's county museums is in trouble. An area of particular concern is the museums' responsibility for developing new areas of knowledge for management of the cultural environment. The museums' ability to participate in the development of management has not only been hurt by the deregulation of contract archaeology, but also by the way management itself began to be used as a political instrument at the onset of the new millennium, starting with the project Agenda Cultural Heritage ( $S w$. Agenda kulturarv).

In Sweden, management of the cultural environment is led by antiquarians employed by public authorities and museums. Antiquarians, usually trained as archaeologists or historians, are culture professionals who use judicial, economic and informative means of control to protect and preserve valuable historical buildings, remains, objects and environments. Antiquarian duties are important as they are connected to the creation of a historical consciousness in society.

In 1976 the organization of management was reformed. Länsmuseer (county museums), Länsstyrelser (County Administrative Boards) and Riksantikvarieämbetet (the National Heritage Board) were each handed distinct responsibilities that are still held today. The museums were given an earmarked grant from the state for developing knowledge about the 
cultural environment (Prop. 20I6/I7:II6 Kulturarvspolitik 20I7:I49). Since 20II the distribution of the grant has been determined at a regional level. With the exception of the county museum of Stockholm, the museums are handed their state funding in competition with the region's fine arts, libraries, archives, film production, arts and crafts, theatre, dance and music (SFS 20I0:201 2 Förordning om fördelning av vissa statsbidrag till regional kulturverksambet 2010; Prop. 2016/I7:I I6 Kulturarvspolitik 2007:I50). In 2009 the government acknowledged that Riksantikvarieämbetet was responsible for leading and coordinating knowledge-building initiatives (Prop. 2009/ıo:3 Tid för kultur 2009:74). According to heritage legislation the board is also responsible for supervising management of the cultural environment in the whole country (SFS I988:950 Kulturmiljölag I kap. 2 S). Länsstyrelserna have since 1976 been responsible for handling a majority of the legal issues connected to management.

\section{THE DEVELOPMENT OF CULTURAL ENVIRONMENT MANAGEMENT}

Through the years, management of the cultural environment has gradually developed. A few decades ago stewardship focused on the protection of monuments such as ancient remains, churches and certain buildings. The image of the past created by the protection of monuments was to a certain extent limited as it mainly appears to have been interested in establishing an awareness of a distant prehistory, Christianization and the state formation process. In the I980s entire environments began to be emphasized as the representation of history increased in complexity. The history of agriculture became a part of antiquarian undertakings as well as built-up environments connected to the history of urbanization (Prop. I987/88:104 Kulturmiljövaird I988:3I). At the turn of the new millennium the image of the past mediated by the antiquarian endeavour was elaborated again when remains of the history of industrialization began to be managed (Riksantikvarieämbetet 200I).

Lately, archaeologists in Sweden have shown a growing interest in the events of the Second World War and the Cold War (Burström et al. 2006; McWilliams 20I3; Axelsson \& Persson 20I6). Battlefield archaeology has been developed as well as garden archaeology (Knarrström 2004; Heimdahl 20I0). Antiquarians have also become interested in the preservation of 2oth-century architecture (Riksantikvarieämbetet 20I7). These examples demonstrate favourable conditions for developing antiquarian undertakings in the future, and thus for antiquarians 
to deliver even more complex understandings of history to the general public. For this to actually happen it is essential that county museums continue to employ archaeologists and heritage curators with the necessary resources to integrate scientific research and information into management of the cultural environment.

\section{THE MARKET}

Contract archaeology was deregulated in the late I990s and today there are numerous private and public enterprises on the market. However, the deregulation is not unique. Nowadays, knowledge about historical buildings, cultural landscapes, and other parts of the cultural environment has also begun to be sold to Länsstyrelser and other customers from a range of businesses. In fact a whole market for consultants has established itself within the area where county museums hold a responsibility for developing regional knowledge about the cultural environment.

The museums have adapted to the new circumstances in different ways. Some of them have sorted their business initiatives into separate organizations. Others have chosen to market their new services as a part of their regular operations. Several museums have claimed that being a part of the market is important for their ability to maintain competence and personnel within the field (Riksantikvarieämbetet 2015:7).

When Länsmuseerna adjust their operations to be competitive on the market they run a risk of neglecting their public duties connected to the development of knowledge. Some museums have also claimed that this is the case (Riksantikvarieämbetet 2015:32). Commercialization has created a situation where vast amounts of experience and knowledge, which was planned to be in the possession of county museums, is now in the charge of organizations that are not responsible for building knowledge to be used in the development of cultural environment management. The system created in 1976 has changed dramatically but a new system has yet to be put in its place.

\section{AGENDA CULTURAL HERITAGE}

The project Agenda Cultural Heritage was launched a couple of years after the deregulation of contract archaeology (Agenda kulturarv 2004a). The project's objective was to recast the antiquarian profession, from a line of work aspiring to solicit knowledge about the past into an activity carried out with the main purpose of being of use to society. Project docu- 
mentation reveals the ambition to shape the preservation and protection of the cultural environment into an instrument for fulfilling the societal needs of multiculturalism (Agenda kulturarv 2002b:4, 2004b:17, $2004 \mathrm{c}: 23)$. An intention was to increase public influence and participation over stewardship. History itself and its physical remains were to be discarded as the singular foundation of the antiquarian profession. Instead, present needs of society were to be honoured (Agenda kulturarv 2004a:6). One of the project's documents describes how participation could be increased at the nation's museums. Caretakers, museum guides, public relations managers, and carpenters should be heard before making decisions about what to protect and preserve (Agenda kulturarv 2002a:9). The established developmental process of gradually integrating new understandings of history into management of the cultural environment was thus to be given up in favour of a clearly anachronistic approach.

The redirection of stewardship that was initiated by Agenda Cultural Heritage over a decade ago is still evident. The strategy Vision för kulturmiljöarbetet 2030, recently launched by Riksantikvarieämbetet, is a clear example (Riksantikvarieämbetet 20I6). Lately, Riksantikvarieämbetet has also claimed that the regional redistribution of state funding to the arts and culture should not be earmarked for the employment of antiquarians at county museums. The argument put forward was that other areas of funding, such as arts and crafts, theatre, film production, etc. can also be construed as kinds of management of the cultural environment (2015/16:RFR4 Är samverkan modellen? 2015:95; Riksantikvarieämbetet $20 \mathrm{I} 7 \mathrm{~b}$ ). Riksantikvarieämbetets claim that areas of culture that are decidedly not responsible for transmitting history to the general public are on par with management of the cultural environment is astonishing. It means that professional actors, musicians, librarians, and others who do not have academic training in history are equated with antiquarians. Though difficult to agree with, the line of thinking at Riksantikvarieämbetet is comprehensible within the context of Agenda Cultural Heritage. Antiquarians with a scientific training in archaeology or history are not required for managing a cultural environment directed at fulfilling the present needs of society.

\section{THE FUTURE FOR ARCHAEOLOGY AT LÄNSMUSEERNA}

The system for integrating new forms of historical knowledge into management of the cultural environment created in 1976 has not only 
been damaged by commercialization. It has also been hurt by the ambition to develop the antiquarian profession into a tool for achieving objectives set by other areas of national policy.

The bill for heritage management presented by the Swedish government in 2017 concludes that the antiquarian profession has repeatedly been used by the state to serve different purposes. Through the years, management of historical remains has been used to glorify royal sovereignty and to construct the notion of a nation (Prop. 20I6/I7:II6 Kulturarvspolitik 2017:20-39). However, the government bill failed to recognize the instrumental use of history that has been an issue in Sweden since the onset of the new millennium.

The ambition of Agenda Cultural Heritage and Riksantikvarieämbetet of turning the antiquarian profession into a tool for serving the needs of society is at direct odds with the objectives of cultural policies originally set in Sweden in 1974. The government's policy for the arts and culture states that culture should be free and independent and not influenced or controlled by the objectives of other areas of national politics (Frenander 20I4).

To create a future for archaeology at Länsmuseerna it is necessary to recognize that the ideas championed by Agenda Cultural Heritage oppose the direction of cultural policy that Sweden's parliament has repeatedly confirmed. The ambition to de-professionalize the antiquarian line of work must be addressed. A necessary first step is the acknowledgment that management of the cultural environment needs to be controlled and developed by publicly employed antiquarians and that scientific knowledge about the past is a fundamental aspect of the antiquarian endeavour. After that the sector needs to begin solving the problems created by the ongoing process of commercialization.

\section{REFERENCES}

Agenda kulturarv. 2002a. Delrapport april 2002. Riksantikvarieämbetet dnr I08I327-2002.

Agenda kulturarv. 2002b. Projektplan. Riksantikvarieämbetet dnr 108-2098-2002.

Agenda kulturarv. 2004a. Människan i centrum: Agenda kulturarvs programförklaring. Stockholm: Riksantikvarieämbetet.

Agenda kulturarv. 2004b. Slutrapport Agenda kulturarv. Riksantikvarieämbetet dnr I08-874-2004. Stockholm: Riksantikvarieämbetet.

Agenda kulturarv. 2004 c. Utvärdering av arbetet med Agenda kulturarv regionalt och på Riksantikvarieämbetet. Riksantikvarieämbetet dnr 108-874-2004.

Axelsson, T. \& Persson, M. 20I6. Ledningsplats Björn och kalla krigets kulturarv. Gotarc Series C. Arkeologiska skrifter 79. Göteborg: Göteborgs universitet. 
Burström, M., Gustafsson, A. \& Karlsson, H. 2006. The Air Torpedo of Bäckebo: Local Incident and World History. Current Swedish Archaeology. Vol. I4. Pp. 7-24.

Frenander, A. 20I4. Kulturen som kulturpolitikens stora problem: Diskussionen om svensk kulturpolitik fram till 20Iо. Möklinta: Gidlund.

Förordning om fördelning av vissa statsbidrag till regional kulturverksambet. $20 \mathrm{IO}$. SFS 20I0:2012. Stockholm: Regeringen.

Heimdahl, J. 20I0. Barbariska trädgårdsmästare: Nya perspektiv på hortikulturen i Sverige fram till I200-talets slut. Fornvännen. Vol. I05. Pp. 265-280.

Knarrström, B. 2004. Hur gick det egentligen till när Skåne blev svenskt: Slagsfältsarkeologi kan kasta nytt ljus över historiska sanningar. Kulturmiljövård. 2004:2. Pp. 47-5I.

Kulturarvspolitik. 2017. Regeringens proposition 2016/I7:1 I6. Stockholm: Riksdagen.

Kulturmiliölag. SFS 1988:950. Stockholm: Kulturdepartementet.

Kulturmiliövård. I988. Regeringens proposition I987/88:I04. Stockholm: Regeringen.

McWilliams, A. 2013. An Archaeology of the Iron Curtain: Material and Metaphor. Diss. Stockholm: Stockholm University.

Riksantikvarieämbetet. 200I. Berättelser om vårt sambälles historia: Svenska industriminnen. Kunskapsavdelningen rapport 200I:5. Stockholm: Riksantikvarieämbetet.

Riksantikvarieämbetet. 20I5. Länsmuseernas och motsvarande museers kulturmiliöarbete: Kartläggning och redovisning av förutsättningarna för samverkan och verksambetsutveckling på regional nivå. Rapport från Riksantikvarieämbetet. Stockholm: Riksantikvarieämbetet.

Riksantikvarieämbetet. 20I6. Vision för kulturmiljöarbetet 2030: Redovisning av regeringsuppdrag om ett offensivt och angeläget kulturmiljöarbete. Stockholm: Riksantikvarieämbetet.

Riksantikvarieämbetet. 20I7a. The 6th Baltic Sea Region Cultural Heritage Forum: From Postwar to Postmodern - 2oth Century Built Cultural Heritage. Stockholm: Riksantikvarieämbetet.

Riksantikvarieämbetet. 20I7b. Yttrande. Kultursamverkan för ett Sverige som håller ihop: Framtida inriktning och utvecklingsmöjligheter för kultursamverkansmodellen. Ds 20I7:8. Riksantikvarieämbetet dnr. I243-20I7.

Tid för kultur. 2009. Regeringens proposition 2009/10:3. Stockholm: Regeringen.

Är samverkan modellen?: En uppföljning och utvärdering av kultursamverkansmodellen. 20I5. Rapporter från riksdagen 20I5/16:RFR4. Stockholm: Riksdagen. 